\title{
AN ASSESSMENT OF WORKERS' SATISFACTION IN ESTATE SURVEYING AND VALUATION FIRMS IN LAGOS STATE, NIGERIA
}

\author{
N. J. Peter, A. S. Oni and O. E. Ogunowo \\ Department of Estate Management, Covenant University Ota, Ogun State, Nigeria \\ O. B. Fateye \\ Department of Estate Management and Valuation, Moshood Abiola Polytechnic, \\ Ogun State, Nigeria.
}

\begin{abstract}
This study examined the levels of satisfaction of employees with the major focus on the staff of estate surveying firms (ESFs) practicing in Lagos State, Nigeria. This was with a view to identify the factors influencing their levels of job satisfaction and analyze the relationship among the influencing factors. Structured questionnaire were administered to 367 ESFs operating in Lagos State out of which 274 representing $74.66 \%$ questionnaire were properly filled, returned and analyzed. The study deployed descriptive statistics such as simple frequency distribution, mean weighted score (MWS), cross tabulation, correlation and one-sample test (t-test). The findings of the study showed that few estate surveyors (17.52\%) expressed satisfaction in the job, $39.42 \%$ of the employees were completely dissatisfied while $43.07 \%$ of them were unsure about their job satisfaction level. The result of cross tabulation showed that, male estate surveyors expressed higher level of dissatisfaction (53.73\%) compared to their female counterparts (33.65\%) in ESFs. From the MWS result, the respondents rated communication (COM: 4.41), fairness and sufficiency of salary (SAL: 4.23), the quality of relationship with supervisor (RLS: 4.23), fairness of organizational policies (ORG: 4.17), reward for good job performance (RWD: 3.85) and quality of relationship with co-workers (RCW: 3.77) as the dominant influencing factors of job satisfaction. The study also discovered strong positive correlation coefficient between COM and COW (.824), SAL and RWD (.775), RLS and COM (.754). At 5\% confidence level, the result of the t-test showed positive contributions of all the influencing factors to employees job satisfaction in estate firms $(p<0.05)$. The study concluded that providing enabling work environment in ESFs should be encouraged for optimal unitization of human and non-human resources. Thus, issues relating to staff welfare should be treated with optimum priority in organizations that desires to achieve efficiency in their operations.
\end{abstract}

Keywords: Employees, Satisfaction, Importance, Influencing Factors. 
Cite this Article: N. J. Peter, A. S. Oni and O. E. Ogunowo and O. B. Fateye, An Assessment of Workers' Satisfaction in Estate Surveying and Valuation Firms in Lagos State, Nigeria, International Journal of Management, 10 (2), 2019, pp. 86-99. http://iaeme.com/Home/issue/IJM?Volume=10\&Issue $=2$

\section{INTRODUCTION}

The satisfaction of employees is an important aspect of their work life in an organization. Employees who are satisfied in their jobs tend to concentrate more, have higher morale and become more loyal, happy, confident ad are more able to perform with good efforts, contributing to the long-term effectiveness and overall success of the organization [1]. Employees are fundamental to the achievement of cooperate goal of every organization. Highly-skilled and best performing workers aid companies in securing competitive advantage. Considering that employees are the greatest asset of an organization it is essential that they are well motivated and given room to fairly explore in a work-friendly environment. Thus, their motivation to work and satisfaction on their job remain a major concern which is largely dependent on the staff management strategy which varies from one organization to another [2]. Satisfaction plays an important role in the decision of an employee whether to stay or leave an organization [3]. Workers tend to demonstrate willingness to stay or join an organization where issues relating to their welfare are carefully handled and fairly treated [4]. It is imperative that that an organization is able to keep its employees and an effective channel to achieving this is to ensure that their workers are satisfied. If such is the case, the tendency of an employee to remain in his job becomes considerably high and may continue for a long time or even through his entire working life.

However, the prevalent situation in most estate firms in Lagos State is that they experience high turnover rate of their staff. This will most likely be attributed to issues with staff satisfaction. It is not unusual that workers have unsatisfactory experiences in their respective occupations. The unsatisfactory experiences range from the simplest such as 'common greetings' to the complex nature of discriminations among workers. Employee turnover has become a major has become a major occurrence in real estate organizations [5]; [6]; [7]. It is therefore necessary that real estate employers trace the root of the problem by first addressing issues relating to staff satisfaction. It is against this background that the study aimed at determining the factors affecting workers' satisfaction as well as assessing the level of satisfaction of employees of estate surveying and valuation firms in Lagos State, Nigeria.

\section{LITERATURE REVIEW}

\subsection{The Concept of Employees' Satisfaction}

In more recent times, workers' satisfaction has become a trending issue; widely study by various researchers around the world for many purposes including organizational, educational and policy reforms. The term workers' satisfaction which is sometimes referred to as job satisfaction or employee job satisfaction has been viewed from different perspectives but, the idea has remained the same in every context. [8], [9], [10] simply defined job satisfaction as how pleased or contented an employee is with his engagement. [11] Described it as the degree of happiness a worker has with his job and working environment. Similarly, [12], [13], [14], identified employee satisfaction to be an attitude that explains the extent to which a worker is fulfilled or gratified in his or her job.

The attitudinal behaviours of employee to job reflect his levels of satisfaction which vary per time and largely depend on the organization's structure and policy. [15], [16] noted that, employees attitude towards their job can be positive (favourable) or negative (unfavourable). [17], [18] explained further that, workers' satisfaction is a collection of feelings which ranges 
An Assessment of Workers' Satisfaction in Estate Surveying and Valuation Firms in Lagos State, Nigeria

from extreme satisfaction to extreme dissatisfaction and the levels are influenced by the type of work, co-workers, supervisors, subordinates and salaries.

\subsection{Factors Influencing Employee's Job Satisfaction}

Literature have categorized employees' satisfaction in to two broad and different types. For instance, [19] named them to include global job satisfaction and job facets satisfaction. The global job satisfaction deals with the total satisfaction derived from the job while the job facet satisfaction on the other hand describes a worker's emotion concerning specific aspects of his job. [20] Identified also, two forms of job satisfactions which they regarded as Intrinsic and Extrinsic job satisfaction. The intrinsic job satisfaction is described as satisfaction arousing from self-emanating motivational factors that influence the worker to be satisfied with his job while on the other hands, extrinsic job satisfaction is the job satisfaction that occurs from external factors such as salary, commendation or promotion.

Moreover, discussions on determinants of workers' satisfactions in literature revolve round three broad factors namely; the organizational, environmental and personal factors [21], [22]. The organization-specific factors include pay/salary, reward, promotion, job securities and organization policies. For instance, [23] stressed that, factors that affect workers' satisfaction such as pay, promotion opportunities, working conditions, amongst others should be attended to in order to increase employees' satisfactory levels. Similarly, [24] noted that salary is a hygiene factor which negates dissatisfaction and improves satisfaction levels of workers. The environmental influencing factors comprises of working environment/conditions, team work, leadership structure, communication, inter-personal relationship among the co-workers, while the personal factors re made up of gender, age and seniority, personality, education level, and tenure.

Employees' satisfactory experiences in different forms of occupations have been studied all over the world. In banking occupation [25; [26]; [27], health sector [28], institutions [29], automobile workshops [30] including real estate sector ([17], [2], [5]). Most of these studies have established a strong relationship between employees' satisfaction and firms' productivity, competitive hedge and customer loyalty.

Furthermore, studies have linked the impacts of workers' satisfactions on both the employees and the employers. For instance, [23] noted that working conditions that are not satisfactory in nature, contributed to high rate of employees' turnover. [31] was of the opinion that friendly working environment decreases the rate of workers' mobility, as such, reduces cost of workers' recruitment and training. [32], [33] stressed that, good strategic staff welfare results to enhancement and maintenance of the company product quality, give the organization a market competitive hedge and improves customer loyalty. In addition, [34] and [35] opined that conducive working environment reduces job stress, improves work performance and increases employees' productivity in an organization. Some empirical studies on factors affecting the job satisfaction of employees include:

[36] Investigated the factors affecting the job satisfaction of employees of Unilever in Kenya and found that intrinsic factors such as autonomy in job, training and development, recognition, work meaningfulness and employee attainment of performance feedback are prominent. In Bahawalpur, [37] discovered that factors that influenced workers' satisfaction include employee empowerment, workplace environment, job loyalty and job performance. [27] Sampled 120 employees of Bank for Investment and Development (BID) in Vietnam and found that income and benefits were among the highest significant factors for employee satisfaction. In Indonesia, [38] examined the work experience of employees of manufacturing company in Yogyakarta and Surakarta. The result showed a positive relationship between employee commitment to organization and satisfaction. 
In real estate industry, Shahriar (2015) examined the degree of job satisfaction of employees in various real estate firms in Dhaka City, Bangladesh. The study deployed descriptive statistics and tau-test to assess the factors influencing workers' satisfaction. The findings showed that factors such as present pay, present job, and opportunity for promotion, supervision and relationship with co-workers were significant to satisfaction. The study also showed that job satisfaction levels were rather unimpressive in real estate companies. Therefore, holistic approach towards ensuring that employees experience job satisfaction should be proposed and adopted in Nigerian real estate industry especially at this time when the country is experiencing economic meltdown and lingering agitations for new workers' minimum wage (WMW).

\subsection{Improving Workers' Satisfaction in Organization}

Maintaining workers' satisfaction is very important to the sustenance and effectiveness of any organization. It helps to prevent the degradation of the companies' market and competitive statuses. Shahriar (2015) identified some measures that are vital to ensuring workers satisfaction which include: the condition of the present job and the pay associated to it, available opportunities for promotion, supervision and relationship with co-workers.

Similarly, Ssegawa (2014) highlighted some more factors importatnt in ensuring job satisfaction in organization. These are: ensuring there is autonomy in job, room for training and development, recognition of participation level of employees to their responsibility, contribution to vision and mission and appreciating employee attainment of set target for performance.

In addition, Sageer et al (2012) proffered the following ways of ensuring workers' satisfaction in the workplace such as: (i) employees should be kept abreast of the company's position, progress, challenges and how they can contribute to the realization of the company's objectives; (ii) making available provisions for training and development programmes in order to build the skills and knowledge base of the employees; (iii) compensation should be given fairly which should be proportionate with the workload of the employee and the same amount as that of his/her co-workers; (iv) adequate opportunities be made for promotion and career advancement of employees; (v) making provision of safe working conditions and good equipment in order to increase the productivity of the workers; (vi) building a corporate culture which entails creating a respectful and amicable atmosphere in the organization where coworkers and supervisors have mutual respect and trust for each other; (vii) giving employees frequent feedback based on their performances as well as constructive and positive suggestions on all areas of his participation in the organization; and (viii) rewarding good performance is one significant way to increase job satisfaction and motivate other employees to be better than satisfactory in their respective fields.

\section{RESEARCH METHOD}

This research was carried out on employees of estate surveying firms (ESFs) in Lagos, Nigeria. According to the 2017 directory of the Nigerian Institute of Estate Surveyors and Valuers (NIESV), there are 877 ESV firms in Nigeria, out of which 367 are operating in Lagos State. The study employed primary source of data which is the use of questionnaire. Self-administered questionnaire was administered on one employee per estate surveying and valuation firm in Lagos State using purposive sampling technique. Only 274 representing $74.66 \%$ were properly filled, retrieved and analyzed and used for the study. The study deployed descriptive statistics such as simple frequency distribution (SFD), cross-tabulation, correlation, mean score, percentage ranking and inferential statistics such as one-sample test (t-stats). 
An Assessment of Workers' Satisfaction in Estate Surveying and Valuation Firms in Lagos State, Nigeria

\subsection{Results}

\subsubsection{Frequency Table on Profile of Respondents}

Table 1 presents the profile of the employees in estate surveying firms (ESFs) in Lagos such as information of age, gender, and marital status, employment status, academic and professional background, salary and current position held in the firm. Data on the age categories of the respondents showed that $2.19 \%$ of the employees fall within the age group of 40-59 while $35.77 \%$ were within the age bracket 20-39years. Employees' age that are less than 20years old and those above 60years account for 5.84 and $6.93 \%$ respectively. Gender information showed that male employees in ESFs accounts for $58.76 \%$ while their female counterparts represents $41.19 \%$. Table 1 also showed that $84.67 \%$ of the ESFs' employees were married, while others were either single, widow or divorcee represent $7.66,4.75$ and $2.29 \%$ respectively. Information on the highest academic and professional qualification of the respondents showed that $48.91 \%$ and $41.24 \%$ had Bachelor of Science Degree and Higher National Diploma respectively and $41.24 \%$ and $20.44 \%$ have attained the cadre of Associate and Fellow of the Nigerian Institution of estate surveyors and valuers. Concerning the status of the respondents in the organizations were they work, $67.52 \%$ holds senior position in their place of work while $32.48 \%$ were still junior staff in their organizations.

Table 1 Profile of the Employees of Estate Surveying Firms (ESFs)

\begin{tabular}{|c|c|c|c|}
\hline Response & Parameter & Frequency & Percentage \\
\hline \multirow{5}{*}{ Age (years) } & $<20$ & 16 & 5.84 \\
\hline & $20-39$ & 98 & 35.77 \\
\hline & $40-59$ & 143 & 52.19 \\
\hline & $\geq 60$ & 19 & 6.93 \\
\hline & Total & 274 & 100.00 \\
\hline \multirow{3}{*}{ Gender } & Male & 161 & 58.76 \\
\hline & Female & 113 & 41.24 \\
\hline & Total & 273 & 100.00 \\
\hline \multirow{5}{*}{ Marital Status } & Single & 21 & 7.66 \\
\hline & Married & 232 & 84.67 \\
\hline & Divorced & 8 & 2.29 \\
\hline & Widow & 13 & 4.75 \\
\hline & Total & 274 & 100.00 \\
\hline \multirow{4}{*}{ Employment Status } & Full time & 204 & 74.45 \\
\hline & Part time & 14 & 5.11 \\
\hline & Contract basis & 56 & 20.44 \\
\hline & Total & 274 & 100.00 \\
\hline \multirow{6}{*}{$\begin{array}{l}\text { Highest Academic } \\
\text { Qualification }\end{array}$} & OND & 11 & 4.01 \\
\hline & HND & 134 & 48.91 \\
\hline & B. Sc & 113 & 41.24 \\
\hline & M. Sc & 12 & 4.38 \\
\hline & Ph. D & 4 & 1.46 \\
\hline & Total & 274 & 100.00 \\
\hline \multirow{3}{*}{$\begin{array}{l}\text { Highest Professional } \\
\text { Qualification }\end{array}$} & Fellow & 56 & 20.44 \\
\hline & Associate & 113 & 41.24 \\
\hline & Probationers/Graduates. & 105 & 38.32 \\
\hline
\end{tabular}




\begin{tabular}{|c|c|c|c|}
\hline Response & Parameter & Frequency & Percentage \\
\hline & Total & 274 & 100.00 \\
\hline \multirow{6}{*}{ Current Position Held } & Partner & 14 & 5.11 \\
\hline & Ass. Partner & 49 & 17.88 \\
\hline & Estate Surveyor & 122 & 44.53 \\
\hline & Asst. Est. Surveyor & 87 & 31.75 \\
\hline & Pupil Surveyor & 2 & 0.74 \\
\hline & Total & 274 & 100.00 \\
\hline \multirow{6}{*}{$\begin{array}{l}\text { Monthly Salary } \\
\left(\mathrm{N}^{\prime} 000\right)\end{array}$} & $10-49$ & 22 & 8.00 \\
\hline & $50-99$ & 130 & 47.03 \\
\hline & $100-149$ & 36 & 13.14 \\
\hline & $150-199$ & 51 & 18.61 \\
\hline & 200 and Above & 36 & 13.14 \\
\hline & Total & 274 & 100.00 \\
\hline
\end{tabular}

\subsubsection{Gender Based Cross-tabulation Analysis}

Table 2 depicts the result of the cross-tabulation analysis of the respondents' highest academic qualification, current position held and monthly salaries based on gender. The result of gender compared with highest academic qualification of the respondents showed that there are more male HND holders $(52.98 \%)$ than females (47.01\%). Amongst BSc holders as well, males $(65.49 \%)$ are still more than females $(34.51 \%)$.

Comparing gender with current position held in the organization, the male respondents recorded highest number in all categories of offices; with $78.57 \%$ of the partners being males as against $21.42 \%$ partners who are females. There are $63.26 \%$ who are male associate partners as against $36.73 \%$ who are females. Male estate surveyors and valuers $(53.27 \%)$ are as well more than the females (46.72\%). For salary between $\mathrm{N} 50,000-\mathrm{N} 99,000,49.23 \%$ are males while $50.76 \%$ are females. This appears to be the first situation where the females are more in number than the males. Salary level of $N 100,000$ to $N 149,000$ comprised of $61.11 \%$ as males

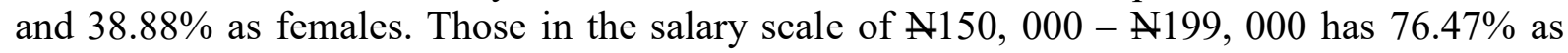
males while only $23.52 \%$ are females.

Table 2 Cross-Tabulation of Employees of ESFs Based on Gender Categories

\begin{tabular}{|c|c|c|c|c|}
\hline \multirow{2}{*}{ Response } & Parameters & $\begin{array}{c}\text { Male Frequency } \\
(\mathbf{\%})\end{array}$ & $\begin{array}{c}\text { Female Frequency } \\
\mathbf{( \% )}\end{array}$ & Total (\%) \\
\hline \multirow{4}{*}{$\begin{array}{c}\text { Highest } \\
\text { Academic } \\
\text { Qualification }\end{array}$} & OND & $4(2.48)$ & $7(6.19)$ & $11(4.02)$ \\
\cline { 2 - 5 } & HND & $71(44.10)$ & $63(55.75)$ & $134(48.91)$ \\
\cline { 2 - 5 } & B. Sc. & $74(45.34)$ & $40(35.40)$ & $113(41.24)$ \\
\cline { 2 - 5 } & M. Sc. & $9(5.59)$ & $3(2.66)$ & $12(4.38)$ \\
\cline { 2 - 5 } & Ph. D. & $4(2.48)$ & - & $4(1.46)$ \\
\hline \multirow{4}{*}{$\begin{array}{c}\text { Current } \\
\text { PositionHeld }\end{array}$} & Total(\%) & $161(100.00)$ & $113(100.00)$ & $274(100.00)$ \\
\cline { 2 - 5 } & Partner & $11(6.83)$ & $3(2.66)$ & $14(5.11)$ \\
\cline { 2 - 5 } & Ass. Partner & $31(19.25)$ & $18(15.93)$ & $49(17.88)$ \\
\cline { 2 - 5 } & Estate Surveyor & $65(53.28)$ & $57(50.44)$ & $122(44.53)$ \\
\cline { 2 - 5 } & Ast. Est. Surveyor & $52(32.30)$ & $35(30.97)$ & $89(32.48)$ \\
\cline { 2 - 5 } & Pupil Surveyor & $2(1.24)$ & - & $2(0.73)$ \\
\hline & Total (\%) & $161(100.00)$ & $113(100.00)$ & $274(100.00)$ \\
\hline
\end{tabular}


An Assessment of Workers' Satisfaction in Estate Surveying and Valuation Firms in Lagos State, Nigeria

\begin{tabular}{|c|c|c|c|c|}
\hline \multirow{2}{*}{ Response } & Parameters & $\begin{array}{c}\text { Male Frequency } \\
(\mathbf{\%})\end{array}$ & $\begin{array}{c}\text { Female Frequency } \\
(\mathbf{\%})\end{array}$ & Total (\%) \\
\hline \multirow{4}{*}{$\begin{array}{c}\text { Employees } \\
\text { Monthly } \\
\text { Income }\end{array}$} & $50-99$ & $64(39.75)$ & $66(58.41)$ & $130(47.45)$ \\
\cline { 2 - 5 } & $100-149$ & $22(13.66)$ & $14(12.39)$ & $36(13.14)$ \\
\cline { 2 - 5 } & $150-199$ & $39(24.22)$ & $12(10.62)$ & $51(18.61)$ \\
\cline { 2 - 5 } & 200 and Above & $27(16.77)$ & $8(7.08)$ & $35(12.77)$ \\
\cline { 2 - 5 } & Total & $161(100.00)$ & $131(100.00)$ & $274(100.00)$ \\
\hline
\end{tabular}

\subsubsection{Employees' Level of Satisfaction in ESFs}

Table 3 presents employees' levels of satisfaction in their job and Table 4 further depicts the satisfactory levels based on gender. In general, the analysis in Tables 3 showed that $1.46 \%$ of the estate surveyors were extremely satisfied, $16.06 \%$ were moderately satisfied, $43.07 \%$ were indifferent on their satisfaction condition, and $35.40 \%$ expresses dissatisfaction while $4.02 \%$ were extremely dissatisfied. This means that, apart from few estate surveyors $(17.52 \%)$ that expressed satisfaction in the job, about $39.42 \%$ employees were completely dissatisfied while those that were unsure of their satisfactory level constitute $43.07 \%$.

Table 4 investigates into opinion of the male and female employees with respect to their level of satisfaction on their job in ESFs. In summary among the male estate surveyors, $19.87 \%$ said they were satisfied, $25.47 \%$ were indifference while $53.73 \%$ expressed dissatisfaction. On the other hand, $34.48 \%$ female estate surveyors expressed satisfactions on their job, $30.31 \%$ were unsure while $33.63 \%$ showed dissatisfaction. In comparison, more male estate surveyors are not satisfied with the working conditions as compared with their female counterpart. Illustration in Table 4 is presented in chart (Fig. 1\&2)

Table 3 Employees' Satisfactory Level on the Job in ESFs

\begin{tabular}{|c|c|c|c|c|c|}
\hline $\begin{array}{c}\text { Level of } \\
\text { Satisfaction } \\
\text { in the Job }\end{array}$ & $\begin{array}{c}\text { Extremely } \\
\text { Satisfy (\%) }\end{array}$ & $\begin{array}{c}\text { Moderately } \\
\text { Satisfied (\%) }\end{array}$ & $\begin{array}{c}\text { Unsure } \\
(\mathbf{\%})\end{array}$ & $\begin{array}{c}\text { Dissatisfied } \\
(\mathbf{\%})\end{array}$ & $\begin{array}{c}\text { Extremely } \\
\text { Dissatisfied (\%) }\end{array}$ \\
\cline { 2 - 6 } & $4(1.46)$ & $44(16.06)$ & $118(43.07)$ & $97(35.40)$ & $11(4.02)$ \\
\hline
\end{tabular}

Table 4 Employees' Satisfactory Level on the Job in ESFs Based on Gender

\begin{tabular}{|l|l|l|l|l|l|l|}
\hline \multirow{2}{*}{$\begin{array}{l}\text { Level of } \\
\text { Satisfaction } \\
\text { in the Job }\end{array}$} & Gender & $\begin{array}{l}\text { Extremely } \\
\text { Satisfy } \\
(\mathbf{\%})\end{array}$ & $\begin{array}{l}\text { Moderately } \\
\text { Satisfied } \\
\text { (\%) }\end{array}$ & $\begin{array}{l}\text { Unsure } \\
(\mathbf{\%})\end{array}$ & $\begin{array}{l}\text { Dissatisfied } \\
(\%)\end{array}$ & $\begin{array}{l}\text { Extremely } \\
\text { Dissatisfied (\%) }\end{array}$ \\
\cline { 2 - 7 } & Male & $11(6.83)$ & $21(13.04)$ & $41(25.47)$ & $57(34.50)$ & $31(19.25)$ \\
\cline { 2 - 7 } & Female & $1(0.85)$ & $38(33.63)$ & $35(30.98)$ & $36(31.86)$ & $2(1.77)$ \\
\hline
\end{tabular}

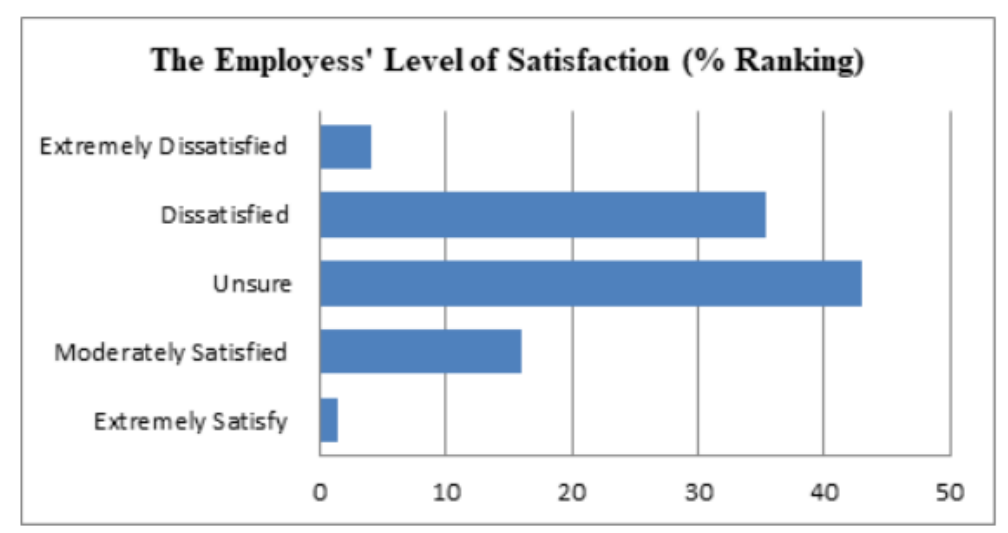

Figure 1 Measurement of ESFs' Employees Levels of Satisfaction 


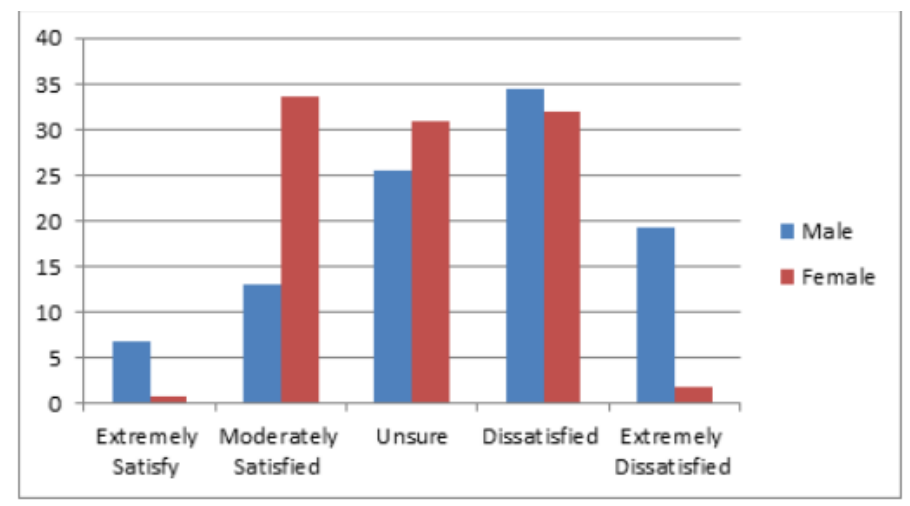

Figure 1 Gender based Employees' Levels of Satisfaction

\subsubsection{Factors influencing the Level of Satisfaction of Employees in ESFs}

The result in Table 5 shows the mean score ranking of the factors influencing employees' level of satisfaction which was based on 5 point Likert scale. The factors with mean score above 3.00 indicates that they are in agreement and bear their weight thus, influencing workers satisfaction level in estate surveying and valuation firms. The result in Table 5 is shown in order (descending) of agreement of the respondents on prominent factors that influence their level of satisfaction in estate surveying and valuation firms. Among the identified influencing factors are communication in the workplace (COM) which has mean of 4.41 and ranked 1st. Fairness and sufficiency of salary (SAL) as well as the quality of relationship with supervisor (RLS) ranked 2nd ranked with mean of 4.23 each. Factors such as fairness of organization policies (ORG), reward for good job performance (RWD) and quality of relationship with co-workers (RCW) with mean of 4.17, 3.85 and 3.77 occupy 4th, 5th and 6th position in the ranking. Opportunities for promotion and level of job security (PRO) with mean of 3.66 both ranked $7^{\text {th }}$ while conducive and safe working environment (WKE), style of leadership (LDS) and quality team work (TWK) with mean score of $3.59,3.54$ and 3.51 ranked $9^{\text {th }}, 10^{\text {th }}$ and $11^{\text {th }}$ position.

Table 5 Factors Influencing Employees Satisfactions in ESFs in Lagos State

\begin{tabular}{|c|c|c|c|c|c|c|}
\hline $\begin{array}{c}\text { Workers' Satisfaction Influencing } \\
\text { Factor }\end{array}$ & Mean & S. D & Min. & Min & Skew & Rank \\
\hline $\begin{array}{c}\text { Communication in the workplace } \\
\text { (COM) }\end{array}$ & 4.41 & .818 & 1 & 5 & 2.735 & 1 \\
\hline Fairness and sufficiency of salary (SAL) & 4.23 & .912 & 1 & 5 & 2.106 & 2 \\
\hline $\begin{array}{c}\text { Quality of relationship with supervisor } \\
\text { (RLS) }\end{array}$ & 4.23 & .966 & 1 & 5 & 1.858 & 2 \\
\hline $\begin{array}{c}\text { Fairness of organizational policies } \\
\text { (ORG) }\end{array}$ & 4.17 & .956 & 1 & 5 & 1.984 & 4 \\
\hline $\begin{array}{c}\text { Rewards for good job performance } \\
\text { (RWD) }\end{array}$ & 3.85 & .961 & 1 & 5 & 1.261 & 5 \\
\hline $\begin{array}{c}\text { Quality of relationship with co-workers } \\
\text { (RCW) }\end{array}$ & 3.77 & .902 & 1 & 5 & 1.394 & 6 \\
\hline $\begin{array}{c}\text { Opportunities for promotion (PRO) } \\
\text { Level of job security (JST) }\end{array}$ & 3.66 & .807 & 1 & 5 & 1.409 & 7 \\
\hline $\begin{array}{c}\text { Conducive and safe working } \\
\text { environment (WKE) }\end{array}$ & 3.59 & .785 & 1 & 5 & 1.872 & 9 \\
\hline Style of leadership (LDS) & 3.54 & .742 & 1 & 5 & 2.034 & 10 \\
\hline Quality team work (TWK) & 3.51 & .821 & 1 & 5 & 1.702 & 11 \\
\hline
\end{tabular}


An Assessment of Workers' Satisfaction in Estate Surveying and Valuation Firms in Lagos State, Nigeria

\subsubsection{Correlation among the influencing factors of Employees' Job Satisfaction}

Table 6 presents degree of association among the identified influencing factors influencing employees' job satisfactions in estate surveying firms. All the highlighted factors showed positive correlation but at varying degrees. Strong correlation coefficients were observed between COM and COW (.824), SAL and RWD (.775), RLS and COM (.754), RLS and COW (7.34), SAL and COM (.724),ORG and COM (.721); TWK and COW (.703), and SAL and RLS (.700). Weak correlation coefficients exist between WKE and RLS (.249), WKE and COW (.252), and WKE and RLS (.264). The positive correlation among the influencing factors of job satisfaction indicate that they all headed for the same direction thus, for example, an enhancement package in in salary which could have been stimulated by reward and promotion of the staff; all contributed to the satisfaction of the employees in the firm.

Table 6 Correlation Analysis among the Influencing Factors of Job Satisfaction

\begin{tabular}{|c|c|c|c|c|c|c|c|c|c|c|c|}
\hline & SAL & REW & PRO & ORG & JST & WKE & TWK & LDS & RLS & COM & RCW \\
\hline SAL & I.00 & & & & & & & & & & \\
\hline RWD & .775 & 1.00 & & & & & & & & & \\
\hline PRO & .625 & .688 & 1.00 & & & & & & & & \\
\hline ORG & .630 & .629 & .681 & 1.00 & & & & & & & \\
\hline JST & .518 & .612 & .526 & .687 & 1.00 & & & & & & \\
\hline WKE & .346 & .514 & .493 & .332 & .626 & 1.00 & & & & & \\
\hline TWK & .567 & .346 & .600 & .533 & .358 & .264 & 1.00 & & & & \\
\hline LDS & .560 & .595 & .440 & .495 & .483 & .535 & .438 & 1.00 & & & \\
\hline RLS & .700 & .612 & .482 & .697 & .539 & .249 & .549 & .493 & 1.00 & & \\
\hline COM & .724 & .586 & .599 & .721 & .503 & .351 & .628 & .609 & .754 & 1.00 & \\
\hline RCW & .619 & .501 & .543 & .688 & .480 & .252 & .703 & .389 & .734 & .824 & 1.00 \\
\hline
\end{tabular}

\subsubsection{Significance of the Influencing Factors to Employees' Satisfaction in ESFs}

In Table 7, the result of the one-sample test reveals that, at 5\% level of significance, all the influencing factors exhibited positive contributions to employees' satisfaction in estate firms. Factor such as job satisfactory influencing factors with t-stats and p-value such as communication $(\mathrm{COM})(T=14.890 ; P=.000)$, team work $(\mathrm{TWK}) \quad(T=14.875 ; P=$ $.002)$, co-worker relationship (RCW) $(T=14.440 ; P=.001)$, leadership style (LDS) $(T=13.865 ; P=.005)$ and workers-supervisor relationship (RLS) $(T=13.865 ; P=.003)$ are significant at $1 \%$ level $(\mathrm{p}<.01)$. Other influencing factors salary (SAL) $(T=10.756 ; P=$ $.011)$, reward (RWD) $(T=10.713 ; P=.029)$, promotion $(\mathrm{PRO})(T=10.281 ; P=.025)$, organization policy $(\mathrm{ORG})(T=10.458 ; P=.048)$, job security $(\mathrm{JBS})(T=12.000 ; P=$ $.028)$ and working environment (WKE) $(T=12.248 ; P=.027)$ were significant at $5 \%$ level $(\mathrm{p}<.05)$. This result implies that all the factors contributed significantly to employees' job satisfaction in ESFs but at varying degree.

Table 7 Relationship among Influencing Factors of Job Satisfaction

\begin{tabular}{|c|c|c|c|c|c|}
\hline \multirow{2}{*}{$\begin{array}{c}\text { Influencing } \\
\text { Factors }\end{array}$} & \multirow{2}{*}{ t-stats } & \multirow{2}{*}{$\begin{array}{c}\text { Sig. } \\
(\mathbf{5 \% )}\end{array}$} & \multirow{2}{*}{$\begin{array}{c}\text { Mean } \\
\text { Difference }\end{array}$} & \multicolumn{2}{|c|}{$\begin{array}{c}\mathbf{9 5 \%} \text { Confidence Interval } \\
\text { Difference }\end{array}$} \\
\cline { 5 - 6 } & & & & Lower & upper \\
\hline SAL & 10.765 & .011 & 1.410 & 1.15 & 1.68 \\
\hline REW & 10.713 & .029 & 1.564 & 1.27 & 1.86 \\
\hline PRO & 10.281 & .025 & 1.590 & 1.28 & 1.90 \\
\hline
\end{tabular}




\begin{tabular}{|c|c|c|c|c|c|}
\hline ORG & 10.458 & .048 & 1.667 & 1.34 & 1.99 \\
\hline JBS & 12.000 & .028 & 1.846 & 1.53 & 2.16 \\
\hline WKE & 12.248 & .027 & 1.769 & 1.48 & 2.06 \\
\hline TWK & 14.875 & .002 & 1.923 & 1.66 & 2.18 \\
\hline LDS & 13.531 & .005 & 1.872 & 1.59 & 2.15 \\
\hline RLS & 13.865 & .003 & 1.744 & 1.49 & 2.00 \\
\hline COM & 14.890 & .000 & 1.769 & 1.53 & 2.01 \\
\hline RCW & 14.440 & .001 & 1.897 & 1.63 & 2.16 \\
\hline
\end{tabular}

\section{DISCUSSION OF RESULTS}

The study investigated the level of job satisfaction of employees in estate surveying and valuation firms and the factors that influenced such satisfaction levels. The study adopted descriptive statistics such cross-tabulation, mean score and percentage ranking to identify the significant factors. Correlation analysis was used to examine the co-movement among the influencing factors and One-sample test (t-statistics) to assess the interaction among the influencing factors.

From the result on the profile of the respondents, one can conclude that estate surveying and valuation firms are dominated by male staffs. The males are also more among the top ranked staffs and they earn more than the females. This findings may be attributed to the nature of the job. The activities carried out by estate surveyors and valuers is such that may require being subjected to harsh weather conditions most of the time and may even require travelling from one location to another sometimes. This maybe challenging for the female surveyors which may force many into other occupations that are more convenient. Concerning the variance in their level of salaries, this may be influenced by the nature of their assignment/duties, working period, academic and professional background, level of risk faced on the job among others of which many females may not want to partake in jobs that needs to be done at odd times like weekends.

Analysis on the employees' levels of satisfaction revealed that $18 \%$ of the respondents expressed satisfaction in the job. Further discussion with the respondents showed that these category of workers were more of the senior staff which constitutes the management team of the firms and any organization will want to do its best not only to keep but also to satisfy them in the interest of the success and progress of the organization. Some employees were indifferent $(43.07 \%)$ about their satisfactory levels. Based on further discussions with the respondents, some of the employees in this category are of the opinion that they are comfortable with the salary per work load and reward on extra job performance but suffer delay in promotion, leave/holidays, and bonus. Some opined that though they earn relatively better compared to other estate surveying firms in their localities, they are however, faced with long hectic working period sometimes including Saturdays and Sunday (especially for female workers). They are also faced with stringent procedure for sponsorship to conferences and workshops. They have difficulty in making out time to be able to embark on career advancement. Some identified lack of benefits such as credit facilities for car and mortgage arrangement which their contemporaries in other organizations enjoy.

Similarly, approximately $40 \%$ of the employees were completely dissatisfied with their job in the ESFs. Further discussion with some workers in this category revealed some of the challenges encountered to include poor staff welfare package (which covers salaries, conditions of work and other benefits), shortage of man-power especially where the few staffs are too overlaboured with activities meant for many hands. Some other causes highlighted include unrealistic targets to meet, unfavourable policies in their firms which are usually tailored towards making excess profit at the expense of staff welfare, poor leadership style, 
discrimination based on certificates, gender, religion, tribe, amongst a few others. Thus, the employees that expressed dissatisfactions and some of those that were indifferent indicated their readiness to leave the firms once they are able to secure another job opportunity elsewhere.

The result from the mean score ranking showed some of the factors that significantly influenced workers satisfaction which are communication in the workplace, fairness and sufficiency of salary, quality of relationship, fairness of organizational policies and reward for good job performance. Communication is a very important factor in every organization. The manner in which it is handled goes a long way to determine the success or failure of any organization especially as it concerns communication with staffs in the organization. Similarly, salary paid to staffs in terms of adequacy and promptness constitute one of the major factors responsible for workers' satisfaction. It serve as the first motivation and determinant whether an employee will be willing to continue with an organization or will disengage from such within the shortest time frame. The salary of a worker is equivalent to his financial strength and purchasing power which implies that workers with low real income has weak purchasing and low standard of leaving. Thus, any employee working in an organization where the income earned is far below his current status (with regards to academic and professional experiences), will tend to be dissatisfied and will be eager to leave such organization once the opportunity arises. Where the salary is reasonably higher or at par with what is paid his/her colleagues in similar organizations within the same locality, the tendency for the employee to be willing to stay tends to be high. Rewards, promotion and opportunities for career advancement are some other significant factors identified that influences employees' satisfaction in estate surveying and valuation firms (see Table 7). These are very fundamental to employee satisfaction because any organization lacking in any of them may often experience employee turnover and will in spend more recruiting new personnel often. This does not help the long run growth and development of the organization.

\section{CONCLUSION AND RECOMMENDATIONS}

The effectiveness and long run success of organizations have been linked to importance placed on employee satisfaction. It is therefore imperative that organization establish measures that will ensure their employee derive a measure of satisfaction on their job.

This study of employees in estate surveying and valuation firms are not satisfied with their jobs which calls for concern for estate surveying and valuation profession and the professional practice. If estate surveyors and estate trainees who are the major staffs of estate firms are expressing dissatisfaction with the job, this portends danger overtime for the firms they work with and the profession at large. Such firms will frequently experience employee turnover and the quality of service rendered to the public will be tampered with. Such staffs will be tempted to indulge in fraudulent practices which will dent the image of the organization and the profession.

Therefore, organizations should endeavor to improve on ensuring these highly rated influencing factors of employees' satisfaction are constantly available in their organization. These factors include: communication, salary, interpersonal relationship, reward and promotion. When this is the case, motivation will be high which will in turn lead to effectiveness and overall success of the organization and health of professional practice.

Conclusively, providing enabling working environment in general and in estate surveying and valuation profession and practice in particular, encourages optimal unitization of human and non-human resources; to ensure these, the following recommendations are made;

i. Real estate firms should be fair and gender sensitive in treating and assigning duties to their employees; 
ii. Issues that bothers on salary, reward, promotion and other associated benefits should be fairly handled to shun undue discrimination;

iii. Firms should encourage good communication system that will prevent conflict of interest and ensure prompt and effective dissemination of information;

iv. Firms should devise means of encouraging good interpersonal relationship among all categories of staff and show case good leadership style;

v. Employees can be motivated by providing good welfare package that covers career advancement, provision of loan facilities and job security with or without a clause.

\section{ACKNOWLEDGEMENT}

We would like to use this medium to formally acknowledge the management of Covenant University, Ota and Center for Research Innovation and Discovery (CUCRID) for paying for this publication. The support is highly appreciated as it greatly motivated the researchers in accomplishing this work.

\section{REFERENCES}

[1] Sageer, A., Rafat, S., and Agarwal, P. Identification of Variables Affecting Employee Satisfaction and Their Impact on the Organization. Journal of Business and Management, 5(1), 2012, pp. 32-39.

[2] Kabir, M. Measuring Employee Job Satisfaction in Real Estate Business: A Study onsome Selected Companies in Bangladesh. International Journal of Social Sciences, 34(1), 2015, pp. 18-30.

[3] Negash, M. The Effects of Job Satisfaction on Employees' Turnover Intention in Addis Ababa branches, Wegagen Banks.co (Master's Thesis). Addis Ababa University, Addis Ababa, Ethiopia, 2004.

[4] Unutmaz, S. Factors Affecting Job Satisfaction of Employees in a Public Institution (Master's Thesis). Graduate School of Natural and Applied Sciences, Middle East Technical University, Ankara, Turkey, 2014.

[5] Bamidele A., and Koleoso, H. Job Satisfaction and Staff Turnover of Estate Surveyors and Valuers in Lagos State. Lagos Journal of Environmental Studies, 8(1), 2016, pp. 1-12.

[6] Bilau, A., Sholanke, A., Ajagbe, M., and Sani, T. Impact of Employee Turnover in small and medium construction firms: A literature review. International Journal of Engineering Research and Technology, 4(2), 2015, pp. 976-982.

[7] Kabir, M. Measuring Employee Job Satisfaction in Real Estate Business: A Study on some Selected Companies in Bangladesh. International Journal of Social Sciences, 34(1), 2015, pp. 18-30.

[8] Moyes, D., and Shao, P., Newsome, M. Comparative Analysis of Employee Job Satisfaction in the Accounting Profession. Journal of Business \& Economics Research, 6(2), 2008, pp. $65-81$

[9] Nkolika J. Peter, Caleb A. Ayedun and Chukwuemeka O. Iroham. Registration into Associate Membership Status of the Nigerian Institution of Estate Surveyors and Valuers (NIESV): The Challenges. International Journal of Civil Engineering \& Technology, 9(10), 2018, pp. $1239-1251$.

[10] Parvin, M., and Kabir, M. Factors Affecting Employee Job Satisfaction of pharmaceutical sector. Australian Journal of Business and Management Research, 1(9), 2011, pp. 113123.

[11] Jhajharia, P., and Gupta, H. A Study of Employee Satisfaction and Its Impact on Employee Retention in Retail Sector. Journal of Business and Management, 17(7), 2015, pp. 1-7.

[12] Nkolika J. Peter, Oluwatosin, B. Fateye, Olayinka, Oloke and Iyanda Praise. Changing urban land use and neighbourhood quality: evidence from Federal Capital Territory (FCT), Abuja, Nigeria. International Journal of Civil Engineering \& Technology, 9(11), 2018, pp. 23-36. 
An Assessment of Workers' Satisfaction in Estate Surveying and Valuation Firms in Lagos State, Nigeria

[13] Kaliski, B. Encyclopedia of Business and Finance ( $2^{\text {nd }}$ ed.). Detroit, MI: Thompson Gale, 2007.

[14] Nkolika Peter, C. Ayedun, C. Iroham, O. Oloke, and L. Amusan, Factors influencing attrition of estate management students in Nigeria: A conceptual framework. Proceedings of the $10^{\text {th }}$ International Conference of Education, Research and Innovation, Seville, Spain, $16^{\text {th }}-18^{\text {th }}$ November, 2017.

[15] Shahriar, S. Job satisfaction of employees: a study on real estate companies in Dhaka City. Journal of Business and Economics, 9(2), 2015, 79-93.

[16] Armstrong, M. A handbook of human resource management practice (10th ed). London, England: Kogan Page Publishing, 2006.

[17] George, J., \& Jones, R. Understanding and Managing Organizational behavior, (5th ed.). New Jersey: Pearson/Prentice Hall, 2008.

[18] N. J. Peter, C. Ayedun, S. Oloyede, O. Iroham, A. Oluwatayo, Gender attrition rate differences among estate management students of Universities in South-West, Nigeria. Proceedings of the $9^{\text {th }}$ International Conference on Education and Learning Technologies, Barcelonia, Spain, $3^{\text {rd }}-5^{\text {th }}$ July 2017. (EDULEARN).

[19] Mueller, C., \& Kim, S. The contented female worker: Still a paradox? In K. Hegtvedt \& J. Clay-Warner (Ed.), Justice: Advances in group processes volume 25, Bingley, UK: Emerald Group Publishing Limited, 2008.

[20] Gathungu, J., \& Wachira W. Job Satisfaction Factors that Influence the Performance of Secondary School Principals in their Administrative Functions in Mombasa District, Kenya. International Journal of Education and Research. 1(2), 2013, pp. 1-15.

[21] Oluwunmi, Adedamola O., Emeghe, Ijeoma, Oluwadamilola, A., Fulani, O. and Peter Nkolia Joy, Akinjare, O. A Gender Inequality and women Discrimination in Real Estate Firms in Lagos State, Nigeria. IBIMA, 3-4 May, 2017, Vienna, Austria.

[22] Javed, M., Balouch, R., \& Hassan, F. Determinants of job satisfaction and its impact on employee performance and turnover intention. International Journal of Learning \& Development, 4(2), 2014, 120-140.

[23] Gregory, K. The importance of employee satisfaction. Journal of the Division of Business \& Information Management, 5, 2011, 29-37.

[24] Robbins, P. Organizational behavior. New Delhi: Prentice - Hall, 2001.

[25] Negash, M. The effects of job satisfaction on employees' turnover intention in Addis Ababa branches, Wegagen Bank s.co (Master's thesis). Addis Ababa University, Addis Ababa, Ethiopia, 2004.

[26] Shaibu, R. Factors influencing job satisfaction and turnover intentions in commercial bank (Master's Thesis). Open University of Tanzania, Dar es Salaam, Tanzania, 2014.

[27] Duc, T., Van, N., Huu, P., \& Tang, H. Study on the factors affecting job satisfaction of employees at BIDV (Bank for Investment and Development of Vietnam). Proceedings of the Second Asia-Pacific Conference on Global Business, Economics, Finance and Social Sciences (AP15Vietnam Conference). Danang, Vietnam, 2015.

[28] Khan, A., \& Aleem, M. Impact of job satisfaction on employee turnover: an empirical study of autonomous medical institutions of Pakistan. Journal of International Studies, 7(1), 2014, 122-132.

[29] Mabimdisa, V. Impact of staff turnover on organizational effectiveness and employee performance at the department of home affairs in the Eastern Cape Province (Master's Thesis) Department of Human Resources Management, Faculty of Management Sciences, Durban University of Technology, KwaZulu-Natal, South Africa, 2013.

[30] Neog, B., \& Barua, M. (2014). Factors influencing employee's job satisfaction: An empirical study among employees of automobile service maworkshops in Assam. SIJ Transactions on Industrial, Financial \& Business Management, 2(7). 305-316.

[31] Son, S. The importance of employee retention, explained 8 ways. 2016. Retrieved from https://www.tinypulse.com/blog/importance-of-employee-retention.

[32] Society for Human Resource Management. Employee Job Satisfaction and Engagement, A research report by the Society for Human Resource management, 2016. 
[33] Amusan Lekan M, Oloniju Leke I, Akomolafe Mariam, Makinde Adebisi, Nkolika-Peter P. Farayola Hezekiah and Faith Osawaru. Adopting Information and Communication Technology in Construction Industry. International Journal of Civil Engineering \& Technology, 9(1), 2018, pp. 739-746.

[34] Okeke, C. The impact of job satisfaction on employee performance in government owned enterprises (Master's thesis). The University of Nigeria, Nsukka, Enugu State, Nigeria, 2010.

[35] Ravine, A. The importance of job satisfaction, 2016. Retrieved from https://www.everjobs.com.bd/en/job-journal/career-advice/the-importance-of-jobsatisfaction/

[36] Ssegawa, G. Factors influencing employee job satisfaction and its impact on employee performance: a case of Unilever Kenya (Master's Thesis). United States International University, Nairobi, Kenya, 2014.

[37] Kawada, T., \& Otsuka, T. Relationship between job stress, occupational position and job satisfaction using a brief job stress questionnaire. Work, (40), 2011, pp. 393-399.

[38] Tarigan, V., \& Ariani, D. Empirical study relations job satisfaction, organizational commitment, and turnover intention. Advances in Management \& Applied Economics, 5(2), 2015, 21-42.

[39] Dr. Charusheela Birajdar and Prof. Akshata Joshi, A Review of Customer Satisfaction for Indian Postal Services. International Journal of Marketing and Human Resource Management, 7(3), 2016, pp. 49-59.

[40] P. K. Gupta and Dr. U. M. Kinange, A Study of Financial Literacy and its Impact on Customer Satisfaction with Special Reference to Banks of Bagalkot District. International Journal of Management, 7(6), 2016, pp. 43-50.

[41] Dr. B. Padmapriya, a Study of Vendor Satisfaction in Outsourcing in Large Scale Public Sector Enterprise, International Journal of Management (IJM), Volume 5, Issue 7, July (2014), pp. 16-29 